\title{
Stakeholder-Identified Barriers, Challenges, and Obstacles in Community Gardens ${ }^{1}$
}

\section{Susan Webb and John Diaz ${ }^{2}$}

\section{Introduction}

Florida Extension agents play a vital role in assisting community members to start and sustain community gardens through site visits, workshops, and educational events on a variety of technical and community building topics. The formation processes of community gardens and the resources available to garden groups vary greatly depending on context, and the locale of potential or existing sites can present unique challenges to gardeners. Community members often call upon agents to assist in addressing these challenges. Unfortunately, many of the challenges community gardeners face can lead to garden loss if not addressed directly.

The authors conducted a Delphi study with an expert panel of 53 community garden stakeholders to create a representative and holistic picture of the barriers, challenges, and obstacles to starting and sustaining community gardens throughout Florida. The findings are presented below. Agents can utilize the results to create program activities that address the primary key challenges identified: community engagement as well as volunteer availability and commitment.

\section{The Delphi Process}

The Delphi technique is an iterative approach designed to elicit consensus among a group of participants to identify program priorities and objectives (Warner, 2015). For this study, participants completed a series of three surveys over the course of several months. The first survey asked participants to list all the barriers, challenges, and obstacles to 1) starting a community garden program and 2) sustaining a community garden program. All of the responses were then compiled into a single list and categorized by the type of challenge or obstacle. These responses were used in the second survey. Participants rated their agreement with each item as a barrier, obstacle, or challenge. These responses were then used to narrow the list down to items that two-thirds of the participants strongly agreed or agreed were indeed a barrier, challenge, or obstacle. This process was repeated for the third survey in which participants achieved consensus on all the items listed.

\section{Findings and Implementation}

The final results of the study indicated that adequate time for community engagement (88.6\%), lack of volunteers $(86.4 \%)$, site selection and access to appropriate land (79.5\%), and low community support (72.7\%) were the most agreed-upon barriers, challenges, and obstacles that community gardeners face in starting and maintaining projects. These results mirror a national study that collected data from gardens across the United States (Drake and Lawson, 2015).

Agents can use these findings to develop programs that provide educational and technical assistance to communities

1. This document is AEC638, one of a series of the Agricultural Education and Communication Department, UF/IFAS Extension. Original publication date March 2018. Visit the EDIS website at http://edis.ifas.ufl.edu.

2. Susan Webb, regional specialized agent, UF/IFAS Extension Southwest District; and John Diaz, assistant professor, Department of Agricultural Education and Communication; UF/IFAS Extension, Gainesville, FL 32611

The Institute of Food and Agricultural Sciences (IFAS) is an Equal Opportunity Institution authorized to provide research, educational information and other services

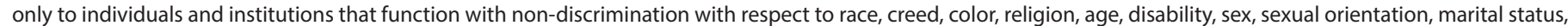

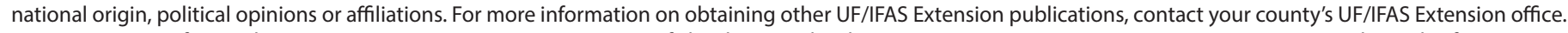
U.S. Department of Agriculture, UF/IFAS Extension Service, University of Florida, IFAS, Florida A \& M University Cooperative Extension Program, and Boards of County Commissioners Cooperating. Nick T. Place, dean for UF/IFAS Extension. 
gardeners to engage their surrounding community and develop meaningful volunteer engagement strategies.

Additionally, the results illustrate the need for agents to work with policymakers to create systemic change in the development of local policies that lessen issues of land ownership and facilitate access to compatible, quality land. The authors conclude with specific, targeted recommendations for how agents can begin to address these challenges through programming as summarized in Table 1 below. The recommendations are based on the authors' experience working with community gardens and knowledge of Extension programming.

\section{References}

Drake, L., \& Lawson, L. (2015). Results of a US and Canada community garden survey: shared challenges in garden management amid diverse geographical and organizational contexts. Journal of Agriculture and Human Values, 32, 241-254. doi:10.1007/s1046

Warner, L. A. (2015). Using the Delphi technique to achieve consensus: A tool for guiding extension programs. WC183. Gainesville: University of Florida Institute of Food and Agricultural Sciences. http://edis.ifas.ufl.edu/wc183 
Table 1. Addressing Challenges through Extension Programming.

\begin{tabular}{|c|c|}
\hline Barrier, Challenge or Obstacle & Extension Program to Address Challenge \\
\hline $\begin{array}{l}\text { Challenges with dedicating the amount of time necessary for } \\
\text { community engagement }\end{array}$ & $\begin{array}{l}\text { Learning events are scheduled with time built in for networking and } \\
\text { sharing among diverse gardens. } \\
\text { Extension-supported garden networks or associations are started in } \\
\text { counties. } \\
\text { Community-building skills are taught at workshops, preferably paired } \\
\text { with teachings on horticultural topics. }\end{array}$ \\
\hline Lack of available and committed volunteers & $\begin{array}{l}\text { Master Gardeners are trained to conduct site visits for new and existing } \\
\text { gardens. } \\
\text { Master Gardeners are trained to deliver hands-on education in gardens. } \\
\text { Master Food and Nutrition Volunteers are trained to deliver nutrition } \\
\text { education tied to the garden. } \\
\text { Agent recommends fostering relationships with social service } \\
\text { organizations, faith-based communities, and colleges as potential } \\
\text { volunteer pools. } \\
\text { If available, the plant clinic is explicitly marketed to gardens as a resource } \\
\text { for identifying and addressing plant and pest problems. }\end{array}$ \\
\hline $\begin{array}{l}\text { Issues in site selection and gaining access to appropriate } \\
\text { land (location, landowner permission, water access, free of } \\
\text { contaminants, bathroom facilities and storage) }\end{array}$ & $\begin{array}{l}\text { Site visits are conducted with new gardens to discuss site characteristics. } \\
\text { Agents work with policymakers to recommend local policies that support } \\
\text { community gardens. }\end{array}$ \\
\hline Inadequate community support & $\begin{array}{l}\text { Encourage and teach potential gardeners to conduct community } \\
\text { outreach prior to starting a garden. }\end{array}$ \\
\hline
\end{tabular}

